\title{
Cultural Aspects of Malaysian English and Russian Medical Profession Names
}

\author{
ISTVAN LENART \\ Institute of Linguistics and Intercultural Communication \\ Sechenov University, Moscow \\ NIKOLAY BUVALIN \\ Sechenov University, Moscow \\ nick.buvalin@gmail.com
}

\begin{abstract}
The translation of medical profession names may challenge even the most experienced translator. Selecting the appropriate equivalents is not always evident: the English term dentist for instance may correspond to either стоматолог [stəmet 'olək] ("тоuth expert”) оr зубной врач [zobn'oj vr'at6] ("tooth doctor") or дантист [dent 'ist] ("dental hygienist") in the Russian language. A physiotherapist can be translated as физиотерапевт [fIzIetırep 'evt]; however a physiotherapist in Russia must necessarily hold a medical doctor degree, in contrast with the practice of most Anglo-Saxon countries. Although the compared terms are often considered as equivalents by bilingual dictionaries (e.g.: surgeon and xupypz [xIr'urk]) (Buvalin and Lenart 2017); however, their denotations and connotations may significantly differ, thus their improper translation may lead to intercultural misunderstandings. In this paper, 17 pairs of English-Russian medical profession names were investigated-the English lexemes coming from the Malaysian variety of the English language - with two competing linguistic methods: the association experiment and a corpus linguistic approach. The authors aimed at identifying semantic dissimilarities between the Malaysian English and the Russian lexemes in a cross-cultural context, from the perspective of both the association experiment and corpus linguistic methods. Firstly, a questionnaire-based association experiment was conducted with 300 Russian and 50 Malaysian medical university students, followed by a contrastive corpus linguistic analysis relying on the Russian National Corpus and the NOW (News on the Web) corpus. Results of the cross-cultural investigation revealed substantial semantic differences between the English and Russian profession names, as well as confirmed the complementary character of the association experiment and the corpus linguistic methods.
\end{abstract}

Keywords: medical profession names; association experiment; corpus linguistics; verbal consciousness; crosscultural investigation

\section{INTRODUCTION}

Translators and interpreters often face challenges identifying the equivalents of medical profession names (Klaudy 1988), due to the cross-culturally dissimilar denotations and connotations of such terms (Yakovlev et al. 2015; 28. Ulyanova, et als. 2016). From the perspective of a lexicographer for instance, the Russian equivalents of the English profession names gynecologist, physiotherapist, dentist and surgeon are: гинеколог [ginik'olək], физиотерапевт [fIzıtırep'evt], стоматолог [stəmet'olək] and хирург [xir'urk]. However, it is clear that these terms cannot be considered as complete equivalents of their English translations, as the English and the Russian words differ both linguistically (syntactically and semantically) and culturally.

In light of the fact that medical profession names appear in specific geographicalcultural contexts, such terms can most effectively be investigated in certain linguo-cultural settings. British English for instance does not only differ from American (or Indian, Malaysian, Ugandan) English in its vocabulary, grammar, syntax and orthography (Lowenberg 1991; Hughes et als. 2005; Tan 2009; Meganathan et als. 2019; Lee et als. 2019), but due to the cultural embeddedness of the medical profession itself, there are noteworthy semantic differences as well. In this paper, the Malaysian English was selected as subject of investigation 
due to the intensive connections between Russia and Malaysia in the field of medical education (an average of approximately 100 Malaysian students start their studies in the biggest Russian medical university, First Moscow State Medical University) (Saravanamuttu 2012).

In case the tasks of a Malaysian dentist for example are contrasted with the responsibilities of a Russian стоматолог (dentist), numerous dissimilarities can be observed. A физиотерапевт (physiotherapist) in Russia must hold a medical doctor (MD) degree, while in Malaysia (or in other countries) this might not be the case. General practitioners may work along dissimilar expectations in Malaysia when compared to their colleagues (mepaneвm) in Russia.

All these examples highlight the fact that these pairs of medical profession names may have different connotations and denotations; furthermore, significantly varying cultural meanings can be attached to them (Yamada, S. 2019). In our paper, some of the semantic differences between the above-mentioned terms were underlined, contrasting the Russian lexemes with the Malaysian English terms, relying on two linguistic research approaches: the association experiment (Karoulov 2000; Ufimtseva 2014) and corpus linguistic methods (Davies 2013).

Other interdisciplinary studies on the borderline of medicine and linguistics can also contribute to the better understanding of the key role of communication between healthcare professionals and patients. Among others, Mattingly studied communication between patients and occupational therapists (Mattingly 1994); Crawford and colleagues investigated the dialogue between nurses and patients (Crawford et al. 1998); while Pilnick conducted research on pharmacist-patient communication (Pilnick 1998). Subsequently, from the 2000s scholars started to lay more emphasis on the cultural perspective of medical communication (Gao et al. 2009). However, such studies focused on a narrow scope of topics, limiting their investigation mainly to physician-patient communication.

The aim of the research is to analyse the intercultural dimension of medical profession names that can influence the communication process inside and outside of healthcare, specifically in the Russian-Malaysian context. Thus, within the framework of this study, Malaysian English and Russian medical profession names are compared in a cross-cultural context, through the analysis and systematic contrast of 17 pairs of English and Russian medical profession names in the English language used in Malaysia, and the Russian language spoken in the territory of the Russian Federation. All participants of our research are Russian and Malaysian medical students of Sechenov Medical University in Moscow.

\section{METHODS}

\section{THE ASSOCIATION EXPERIMENT AS A LINGUISTIC RESEARCH METHOD}

The association experiment (Karaulov 2000, Cherkasova and Ufimtseva 2014, Ufimtseva 2014; Lenart 2017) is a linguistic research method widely applied by the Moscow School of Psycholinguistics (Leontiev 1978, Sorokin 1985, Tarasov 1996). Based on Vigotsky's revolutionary works of cultural-historical psychology and psycholinguistics (Vigotsky 1934) followed by Leontiev's Activity theory (Leontiev 1978), Markovina's Lacuna theory (Markovina 1983, 2011) and further theoretical works (Sorokin 1985), a consistent conceptual framework and linguistic research methodology took shape in the framework of the Moscow School of Psycholinguistics. An underlying technical term of this school of thought is verbal consciousness (языковое сознание) or linguistic consciousness. In this context, Tarasov states that "Images of language consciousness comprise mental knowledge developed by a person primarily in speech communication and sensory knowledge which appears in the mind as a 
result of processing of perceptual data received from sense organs during object-oriented activity" (Tarasov 2000:3).

Ufimtseva contends (Ufimtseva 2014) that verbal consciousness can be investigated by constructing the associative verbal networks of native speakers or culture bearers. Such networks can be identified and demonstrated by the utilisation of the association method, also coined as the association experiment, in which native speakers of a certain language are given word-stimuli and their reactions are recorded, counted and systemically stored in a searchable database. Within the framework of the Moscow School of Psycholinguistics, based on the association method, several associative dictionaries were created, including the Russian Associative Dictionary (RAD 2002), which was compiled between 1986-1996, based on a large-scale associative experiment with 6,600 Russian individuals (university students); followed by the Russian Regional Associative Dictionary (Shaposnikova and Romanenko 2014, 2015); and the Slavic Associative Dictionary (Ufimtseva et als. 2004), to mention but a few examples.

The association experiment is a fundamental method of investigation of verbal consciousness: Thus, a questionnaire-based association experiment was conducted on the 17 pairs of medical profession names with 300 Russian and 50 English-speaking Malaysian respondents, then compared the results with the data of the Russian Associative Dictionary (Karaulov 2002) and the Associative Thesaurus of English (Kiss et al. 1973). The reason for the unbalanced number of respondents is the fact that less Malaysian students are available at Sechenov Medical University, Moscow where the research was conducted. Russian and Malaysian freshmen of the Moscow medical university were selected to the association experiment, due to the fact that they represent one of the biggest group of foreign students in the aforementioned institution. Russian participants' mother tongue is the Russian language, and they speak English as a second language. Similarly to Malaysian respondents who speak English as second language besides Malaysian as their native tongue.

\section{DESCRIPTION OF OUR ASSOCIATION EXPERIMENT}

A questionnaire-based association experiment was conducted with 300 Russian and 50 Malaysian medical university students. The questionnaires comprised the following three parts: (1) personal data; (2) the association experiment, and (3) an intercultural communication test. In this paper, the authors limit themselves to the discussion of the association experiment; the intercultural communication test are analysed in a separate publication (Buvalin 2018).

The association experiment contained the following 17 Russian profession names and their 17 English equivalents: хируре /surgeon; терапевm /general practitioner; реабилитолог /rehab specialist; анестезиолог /anesthesiologist; врач спортивной медицины /specialist in sports and exercise medicine; пластический хирург /plastic surgeon; рентгенолог /radiologist; геронтолог /gerontologist; гинеколог /gynaecologist; акушер /obstetrician; сексолог /sexologist; ортопед /orthopedist; психотерапевт /psychotherapist; патологоанатом /pathologist; врач общественного здоровья и здравоохранения /public health specialist; физиотерапевт /physiotherapist; and стоматолог /dentist.

The participants - students of Sechenov First Moscow State Medical University - took part in the research on a voluntary basis. Respondents were freshmen who joined the university eight months before; consequently, their verbal consciousness has not been heavily influenced by the medical education system. Respondents were given 20 minutes to fill out the questionnaires which were compiled in Russian and in English respectively. After reaching the time limit, they were asked to stop, regardless of whether they had finished. Students were requested to write down the first three words for each profession name that came to their mind 
when hearing those medical profession names. The experiment was done face-to-face, with printed questionnaires.

\section{DESCRIPTION OF OUR CORPUS LINGUISTIC ANALYSIS}

As a second research method, the 34 medical profession names were investigated relying on the Russian National Corpus (Ruscorpora 2003-2019) and the Malaysian sub-corpus of the English-language corpus: News on the Web (NOW 2010-2019). Taking the aforementioned arguments about the linguistic and cultural differences between British, American and Malaysian English - besides other varieties of the English language - into account, the Malaysian sub-corpus was selected, in order to obtain a more precise description of the culturally embedded use of the discussed medical terms in Malaysia. The Malaysian sub-corpus of NOW corpus consists of approximately 214 million words from Malaysian online news sites including Citizen Journalist Malaysia, Daily Express, Malay Mail, Free Malaysia Today, and many more (NOW 2010-2019). With both the Russian National Corpus and the Malaysian sub-corpus of NOW corpus, an analysis and comparison of the collocates of the mentioned profession names were conducted for two part-of-speech categories: nouns and adjectives.

In each case, the top-5 collocates were identified and compared. Top-5 English nouns were selected from the collocations within the environment of $+/-3$ words from the profession names of the Malaysian sub-corpus of the NOW database, while the preceding nouns that followed the search terms from the Russian corpus were ranked based on frequency. Adjectives were selected from both NOW (Malaysian sub-corpus) and Ruscorpora, taking into consideration the frequency of the word standing before the profession names. When analysing the results, the collocates of doctor, $d r, G P$ (general practicioner), врач (doctor) were excluded from the results, as they were so frequently associated with almost all profession names that omitting them allowed us to display more, and hopefully more relevant linguistic data.

\section{RESULTS}

\section{RESULTS OF THE ASSOCIATION EXPERIMENT}

The results of our association experiment revealed that the total number of associations moves on a wide scale regarding the different profession names. Some stimulus-words evoked numerous associations, while others resulted in more modest numbers. Based on this observation the medical profession names were grouped into three categories depending on the number of associations evoked by them: medical profession names with (1) a strong associative field, (2) an average-strength associative field, and (3) a weak associative field.

In the Russian context, medical profession names with a strong associative field (with 400+ associations) included стоматолог (dentist) (446), рентгенолог (radiologist) (443), акушер (obstetrician) (441), анестезиолог (anesthesiologist) (431), and патологоанатом (pathologist) (416). Average associative strength (from 300 to 400 associations) was observed in the following cases: хирург (surgeon) (396), гинеколог (gynесologist) (358), врач спортивной медицины (specialist in sports and exercise medicine) (350), пластический хирург (plastic surgeon) (326), and реабилитолог (rehab specialist) (323). A weak associative field (fewer than 300 associations) was identified for opmoned (orthopedist) (295), сексолог (sexologist) (262), геронтолог (gerontologist) (213), терапевт (general practitioner) (195), физиотерапевт (physiotherapist) (143), психотерапевт (psychotherapist) (118), and врач общественного здоровья и здравоохранения (public health specialist) (109). 
The English terms were grouped in a similar manner with the following results. Strong associative field (with 60+ associations): dentist (113), radiologist (106), obstetrician (70), surgeon (66), and plastic surgeon (61). Average-strength associative field (from 45 to 60 associations) was typical for: orthopedist (56), physiotherapist (52), psychotherapist (51); general practitioner (52), gynecologist (49), anesthesiologist (46), and specialist in sports and exercise medicine (45). The following terms can be characterised with a weak associative field (fewer than 45 associations): rehab specialist (37), gerontologist (33), sexologist (32), and public health specialist (27).

The top-3 profession names with the strongest associative fields coincided in the two languages/cultures: стоматолог (446) - dentist (113), рентгенолог (443) - radiologist (106), and акушер (441) - obstetrician (70). According to our empirical data, it can be stated that these profession names implied the most powerful association fields in both cultures (meanwhile, their perception differed significantly). On the other hand, medical profession names with a weak associative field coincided in the two groups for these items: геронтолог (213) - gerontologist (33), сексолог (262) - sexologist (32), and врач общественного здоровья и здравоохранения (109) - public health specialist (27).

Respondents presumably have stronger emotional ties to stimulus-words including dentist (стоматолог), and obstetrician (акушер) due to closer and more frequent personal experiences with representatives of these professions. In the case of the profession names such as sexologist (сексолог), and gerontologist (геронтолог) linguistic taboo probably contributes to the more modest number of associations.

The profession name with the weakest associative field in both groups was врач общественного здоровья и здравоохранения (public health specialist), confirming that this term was the least familiar to our respondents. Surprisingly, mepanesm (general practitioner) ended in the group with a weak associative field, notwithstanding the fact that it is a more widespread and less specialised profession name compared to the others.

Table 1 summarises the top- 5 results of the association experiment and gives an insight into the perception of profession names in the two cultures, as displayed below.

TABLE 1. Results of our association experiment: top-5 associations of medical profession names

\begin{tabular}{|c|c|c|}
\hline No. & Associations of Russian medical profession names & Associations of English medical profession names \\
\hline 1. & $\begin{array}{l}\text { хирура: операиия (surgery) (125); скальпель (scalpel) } \\
\text { (112); кровь (blood) (112); врач (physician) (28); } \\
\text { ответственность (responsibility) (19) }\end{array}$ & $\begin{array}{l}\text { surgeon: blood (14); surgery (14); scalpel (14); scrubs } \\
\text { (13); operating theater (11) }\end{array}$ \\
\hline 2. & $\begin{array}{l}\text { mерапевт: очередь (qиеие) (66); справки (medical } \\
\text { certificate) (37); поликлиника (polyclinic) (34); врач } \\
\text { (physician) (31); стетоскоn (stethoscope) (27) }\end{array}$ & $\begin{array}{l}\text { general practitioner: stethoscope (16); medicine (11); } \\
\text { patient (9); ECG (9); hard work (5) }\end{array}$ \\
\hline 3. & $\begin{array}{l}\text { реабилитолог: реабилитация (rehab) (113); } \\
\text { восстановление (recovery) (91); помощь (help) (49); } \\
\text { травма - (trauта) (49); физкультура (physical } \\
\text { education) (21) }\end{array}$ & $\begin{array}{l}\text { rehab specialist: rehabilitation (11); sports (8); drugs } \\
\text { (8); athletes (5); physiotherapy (5) }\end{array}$ \\
\hline 4. & $\begin{array}{l}\text { анестезиолог: наркоз (narcosis) (104); операция } \\
\text { (surgery) (102); анестезия (anesthesia) (95); сон } \\
\text { (sleep/dream) (85); укол (injection) (45) }\end{array}$ & $\begin{array}{l}\text { anesthesiologist: drugs (11), anesthesia (11), needle } \\
\text { (9); operation (8); sleep (7) }\end{array}$ \\
\hline 5. & $\begin{array}{l}\text { врач спортивной медицины: физкультура } \\
\text { (physical education) (173); спорт (sports) (64); } \\
\text { здоровье (health) (57); yпражнение (exercise) (31); } \\
\text { группа здоровья (health group) (25) }\end{array}$ & $\begin{array}{l}\text { specialist in sports and exercise medicine: sports (15); } \\
\text { athlete (12); exercise (8); equipment (6); smart (4) }\end{array}$ \\
\hline 6. & $\begin{array}{l}\text { пластический хирура: красота (beauty) (94); груды } \\
\text { (breasts) (60); операция (surgery) (60); лищо (face) } \\
\text { (58); нос (nose) (54) }\end{array}$ & $\begin{array}{l}\text { plastic surgeon: beauty (16); Korea (15); liposuction } \\
\text { (11); cosmetic (10); nose (9) }\end{array}$ \\
\hline 7. & $\begin{array}{l}\text { рентгенолог: рентген (X-ray) (128); снимки (scans) } \\
\text { (112); кости (bones) (96); перелом (fracture) (56); } \\
\text { облучение (exposure) (51) }\end{array}$ & $\begin{array}{l}\text { radiologist: } X \text {-ray (51); MRI (24); CT-scan (20); bone } \\
\text { (6); radiation (5) }\end{array}$ \\
\hline
\end{tabular}




\footnotetext{
8. геронтолог: старость (old age) (108); болезни (diseases) (31); возраст (age) (28); пожилой (elderly) (25); старение (aging) (21)

9. гинеколог: женщина (woman) (130); кресло (chair) (96); беременность (pregnancy) (55); осмотр (examination) (41); менструации (menstruations) (36)

10. акушер: роды (delivery) (196); deтu (children) (115); ребенок (child) (62); жизнь (life) (35); рождение (birth) (33)

11. сексолог: секс (sex) (115); проблемы (issues) (52); отнотения (relations) (49); семья (family) (26); психология (psychology) (20)

12. ортопед: плоскостопие (flat foot) (97); cmona (foot) (65); стельки (insoles) (46); ноги (legs) (46); кости (bones) (41)

13. психотерапевт: психика (mentality) (40); психология (psychology) (21); расстройство (disorder) (20); проблемы (issues) (19); помощьь (help) (18)

14. патологоанатом: труп (corpse) (167); морг (morgue) (107); смерть (death) (64); вскрытие (autopsy) (60); холод (cold) (18)

15. врач общественного здоровья и здравоохранения: здоровье (health) (42); врач (physician) (22); здравоохранение (public health) (20); общество (society) (16); охрана (security) (9)

16. физиотерапевт: прочедуры (procedures) (42); лечение (treatment) (28); восстановление (recovery) (26); прогревание (warm ир) (25); physician (врач) (22)

17. стоматолог: зубы (teeth) (254); боль (pain) (62); пломбы (fillings) (53); кариес (caries) (42); брекеты (braces) (35)

gerontologist: aging (11); old (9); elderly (5); old people (5); nursing homes (3)

gynecologist: baby (14); woman (10); vagina (9); reproductive system (8); menstrual (8)

obstetrician: baby (27); pregnancy (21); childbirth (9); pregnant woman (8); menstrual cycle (5)

sexologist: sex (12); sexuality (7); relationship (5); counseling (4); education (4)

orthopedist: foot (19); leg (18); ankle (8); lower limb (8); massage (6)

psychotherapist: mental (21); emotion (10); depression (8); counseling (8); brain (4)

pathologist: blood (13); disease (13); microscope (8); histology (5); slide (5)

public health specialist: data (8); social (5); health (5); disease (5); epidemiologist (4)

physiotherapist: exercise (14); rehabilitation (14); movement (9); injury (8); therapy (7)

dentist (113): teeth (49); braces (45); gum (7); money (7); pain (5)
}

Top-5 associations revealed both similarities and differences between Russian and English medical profession names. In six cases the perception of language users proved to be almost identical, including the terms: surgeon (хирург) (the top-3 associations: blood, surgery, and scalpel coincided); dentist (стоматолог) (three of the top-6 associations coincided including: teeth, pain and braces); radiologist (рентгенолог) (top-3 associations were almost identical: X-ray, scan/CT-scan/MRI and bones); gerontologist (геронтолог) (almost all of the top-5 associations are connected to aging, old people and elderly); orthopedist (opmoned) (the majority of associations were connected to foot or leg); and anesthesiologist (анестезиолог) (most associations referred to operation/surgery, anesthesia and sleep/dream).

In the case of three pairs of medical profession names, remarkable differences were identified between the perception of the English and Russian terms. The most dissimilar associations can be observed in the case of general practitioner (mерапевm) (the Russian term is connected to queuing [очередь] and to medical certificates [справки]; meanwhile, the English term is mainly associated with technical devices and medical items [stethoscope, ECG, medicine]). Another example of significantly different associative fields was pathologist (патологоанатом) (the Russian perception was connected to corpse and death, the English term evoked more science-related expressions including disease, microscope and histology). The third and last evidence of highly dissimilar associations was physiotherapist (физиотерапевт): The top-3 Russian associations were прочедуры (procedures), лечение (treatment), and восстановление (recovery), while the English term was associated with exercise, rehabilitation, and movement.

Eight pairs of medical profession names displayed a mixed character, showing both similarities and considerable differences in perception. These terms were as follows: реабилитолог - rehab specialist; врач спортивной медицины - specialist in sports and 
exercise medicine; пластический хирург - plastic surgeon; гинеколог - gynесologist; акушер - obstetrician; сексолог - sexologist; nсихотерапевm - physiotherapist; and врач общественного здоровья и здравоохранения - public health specialist. The following results of the data can be highlighted: (1) differences based on cultural traits (i.e.: Malaysian respondents associated Korea with a plastic surgeon); (2) a dissimilar stress on a general/everyday approach contrasted with a more technical/medical/scientific approach (i.e.: the Russian term акушер was associated with children, life, birth, while the English profession name obstetrician evoked menstrual cycle; (3) differences related to practical/country-related facts, such as a plastic surgeon's activity was connected to nose, face and breasts in Russia, while Malaysian respondents mentioned liposuction besides nose.

Finally, (4) the profession names and their linguistic, syntactic forms themselves influenced the answers (i.e. врач общественного здоровья и здравоохранения [public health specialist, literally: doctor of societal health and health protection] evoked both oбщество (society), and охрана (security), as the term itself contains both morphemes/lexemes.

\section{A COMPARISON OF THE RESULTS WITH COLLOCATIONS IN ASSOCIATIVE DICTIONARIES}

The results of our association experiment were contrasted with the data of the Russian Association Dictionary (RAD) (Karaulov 2002) and the Associative Thesaurus of English (Kiss et al. 1973). Table 2 displays those medical profession names that were found in at least one of the above-mentioned databases. As Table 2 suggests, a limited number of the searched terms are among the stimulus-words of the two associative dictionaries/thesauri.

The associations of the very few (four) results of the dictionaries could not essentially contribute to the outcome of our association experiment. The associations of the terms хирург (surgeon); mерапевm (general practitioner); surgeon and dentist showed an overall resemblance to the results discussed under the previous point (3.1.). Besides, the findings confirmed that the Russian terms reflected a more personal, individual-oriented perception of medical professionals, namely by such adjectives as опытный (experienced) and хороший (good).

TABLE 2. Results of our association experiment: top-5 associations of medical profession names

\begin{tabular}{|c|c|c|}
\hline No. & $\begin{array}{c}\text { Russian Association Dictionary } \\
\text { Top-5 associations, stimulus-to-reaction (frequency), } \\
\text { Data retrieved: 29/03/2018 } \\
\end{array}$ & $\begin{array}{c}\text { Associative Thesaurus of English } \\
\text { Top-5 associations, } \\
\text { stimulus-to-reaction (frequency) } \\
\end{array}$ \\
\hline 1. & $\begin{array}{l}\text { хирург: скальпель (scalpel) (10); опытный } \\
\text { (experienced) (5); хороший (good) (5); нож (knife) } \\
\text { (4); режет (cuts) (4) }\end{array}$ & $\begin{array}{l}\text { surgeon: knife (25); operation (6); cut (4); hospital } \\
\text { (3); brain (2) }\end{array}$ \\
\hline 2. & $\begin{array}{l}\text { терапевт: больница (hospital) (4); детский } \\
\text { (children's) (3); лечит (cures) (3); хирург (surgeon) } \\
\text { (3); хороший (good) (3) }\end{array}$ & general practitioner: - \\
\hline 3. & стоматолог: - & $\begin{array}{l}\text { dentist: teeth (30); pain (14); chair (11); tooth (9); drill } \\
\text { (8) }\end{array}$ \\
\hline
\end{tabular}

\section{ANALYSIS OF RUSSIAN AND ENGLISH PROFESSION NAMES WITH CORPUS LINGUISTIC METHODS (NOW, RUSCORPORA)}

The collocates of the discussed medical profession names were investigated in two part-ofspeech categories (nouns, and adjectives) in Ruscorpora and in the Malaysian sub-corpus of NOW corpus. Table 3 displays the top-5 noun collocates of the terms, while Table 4 contains the top-5 adjectives.

Table 3 presents the top-5 noun collocates of the 29 terms that were found in one of the two corpora. In five cases (1. пластический хирург [plastic surgeon]; 2. врач спортивной медицинь [specialist in sports and exercise medicine]; 3. специалист в области 
организачии здравоохранения и общественного здоровья [public health specialist]; 4. rehabilitation specialist; 5 . orthopaedist or orthopedist) the term was not included in the database.

TABLE 3. Top-5 noun collocates of medical profession names in corpora: NOW and Ruscorpora*

\begin{tabular}{|c|c|c|}
\hline No. & $\begin{array}{c}\text { Russian (Ruscorpora) } \\
\text { Top-5 nouns preceding (frequency) -1 NOUN, Data } \\
\text { retrieved: } 18 / 03 / 2018\end{array}$ & $\begin{array}{c}\text { English (NOW, Malaysian sub-corpus) } \\
\text { Top-5 collocates (frequency) +/-3 NOUN } \\
\text { Data retrieved: } 26 / 03 / 2018\end{array}$ \\
\hline 1. & $\begin{array}{l}\text { xирург: нож (knife) (43); рук (hand) (42); год/лет (year) } \\
\text { (26); операция (surgery) (17); помощьь (help) (14) }\end{array}$ & $\begin{array}{l}\text { surgeon: plastic (55); consultant (32); system (27); } \\
\text { hospital (20); hand (16) }\end{array}$ \\
\hline 2. & $\begin{array}{l}\text { mерапевт: профессор (professor) (8); хирург } \\
\text { (surgeon) (8); стоматолог (dentist) (6); } \\
\text { гештальт (gestalt) (5); специиалист (specialist) (5) }\end{array}$ & $\begin{array}{l}\text { general practitioner: solution (5); clinics (5); } \\
\text { dentists (5); care ( } 2) ; \text { fees }(2)\end{array}$ \\
\hline $\begin{array}{l}3 . \\
4 .\end{array}$ & $\begin{array}{l}\text { реабилитолог: рекомендации (recommendations) (2) } \\
\text { анестезиолог: хирург (surgeon) (6); реаниматор } \\
\text { (reanimator) (4); ассистент (assistant) (3); }\end{array}$ & $\begin{array}{l}\text { rehabilitation specialist: - } \\
\text { anesthesiologist: college (2); clinic (1); care (1); } \\
\text { surgeon (1); standard (1) }\end{array}$ \\
\hline
\end{tabular}
(2); машину (machine) (2); сестра (nurse) (2); сияние (radiation) (2)

5. пластический хирург: -

6. рентгенолог: обезьянку (monkey) (2); профессор (professor) (2); paботу (job) (2); - (+27 items)

7. еронтолог: ассоциации (associations) (1); большинство (majority) (1); Генрихов (Henricks) (1); группы (groups) (1); жена (wife) (1); жизни (life) (1); коллеги (colleagues) (1); специалиста (specialist) (1); ученый (scientist) (1); Фролькис (Folkis) (1); языке (language) (1)

8. гинеколог: акушер (obstetrician) (61); nрофессор (professor) (8); хирург (surgeon) (6); женщина (woman) (5); осмотр (checkup) (4)

9. акушер: интерн (intern) (6); лейб (personal) (4); роль (role) (4); книга (book) (3); гинеколог (gynecologist) (2); мама (mother) (2); отношения (relationship) (2)

10. скколог: комментарий (comments) (3); записок (notes) (3); андрологу (andrologist) (2); ассоциащии (associations) (2); гинеколог (gynecologist) (2); психолог (psychologist) (2); nсихотерапевт (psychotherapist) (2); целитель (healer) (2)

11. ортопед: хирург (surgeon) (7); стоматолог (dentist) (4); гинеколога (gynecologist) (2) - (+21 items)

12. психотерапевт: психолог (psychologist) (12); помощь (help) (8); роль (role) (5); астеник (asthenic) (4)

13. патологоанатом: заключение (closing)(8); Асин (Asin) (3); зрения (view) (2); нож (knife) (2); работу (job) (2); частности (detail) (2)

14. специалист в области организации здравоохранения и общественного здоровья: -

15. физиотерапевт: терапевт (therapist) (2); жена (wife) (1); Ирина (Irina) (1); логопеда (speech therapist) (1); пенсии (pension) (1); профессионалов (professional) (1); профессором (professor) (1); содействии (assistance) (1); талант (talent) (1); травматолога (traumatologist) (1)

16. стоматолог: кабинете (office) (5); посещение (visit) (5); рекомендаиия (recommendation) (4); nana (father) (3); neduampul (pediatricians) (3)

plastic surgeon: plastic (52); founder (2); consultant (2); city (1); watches (1) radiologist: consultant (4); pathologist (3); odontologist (3); hospital (2); passion (1) gerontologist: results (1); journal (1); executive (1); director (1)

gynecologist: obstetrician (3); women (1); survey (1); office (1); moment (1)

obstetrician: gynecologist (50); consultant (33); hospital (4); man (3)

sexologist: assembly (2); therapist (1); relationship (1); countries (1); coach (1)

orthopedist: -

psychotherapist: psychologist (3); mediator (2); psychiatrist (2); priest (2); worker (2) pathologist: report (14); army (14); col. (13); hospital (12); colonel (10)

public health specialist: health (9); public (1); prof (1); disease (1); director (1)

physiotherapist: trainee (8); nurses (6); therapist (4); consultant (4); student (4)

dentist: visit (11); people (6); ratio (5); room (5); years (4)

*If the words are not in the nominative case, then their original form was applied as it appears in the corpus

In both corpora a primary result for the noun collocates of the investigated medical profession names was врач/доктор/doctor. Although not all of the selected professions require 
a medical doctor's degree, the phenomenon is understandable, as the investigated medical profession names are hyponyms of the word doctor. Besides stating the above, these results were omitted from the tables, as they appeared in almost all cases and would have superseded further valuable results. It can also be noted that in the Russian language such collocations as врач-хирург (doctor-surgeon) or врач-сексолог (doctor-sexologist) are used in a widespread manner in both written and oral communication - this can be another reason for the high frequency of these words.

Based on the 29 top-5 noun results, the conclusion can be drawn that some profession names can be detected in high-frequency collocation with another semantically adjacent profession name, including гинеколог (gynecologist) and акушер (obstetrician); nсихотерапевт (psychotherapist) and nсихолог(psychologist); anesthesiologist and surgeon; radiologist and pathologist, etc. In these cases, both terms appear in the association field of the other. The corpus linguistic methods proved to confirm the phenomenon observed by the association experiment, and further fine-tune the results. It is interesting to note that the investigation of the noun collocates revealed such morphological differences as реаниматор (reanimator) and реаниматолог (resuscitator) (both collocates of анестезиолог [anestesiologist]). It can be observed that in the Russian language the suffix -олог may signal that the profession requires higher education. Реаниматор is the equivalent of reanimator, meanwhile реаниматолог can be translated to English with a different lexeme: resuscitator. The latter requires medical higher education, the former does not.

As stated above, medical profession names can be found in the proximity of each other in the two corpora. In the investigated material, based on the top-5 noun associations (Table 3) of the stimulus-words, хирург (surgeon) was the most frequently co-occurring term. It was identified in the vicinity of four profession names: терапевm (general practitioner); анестезиолог (anesthesiologist); гинеколог (gynecologist); ортопед (orthopedist).

A significant quantity of culture-bound information appeared as a result of the corpus linguistic research: Table 3 displays words such as Фролькис (Frolkis) as a collocate of геронтолог (gerontologist) (Vladimir Frolkis, an outstanding Soviet pathologist of the $20^{\text {th }}$ century); and Асин (Asin) for патологоанатом (pathologist) (Isaak Asin, a Soviet pathologist). At the same time, several collocates can be considered as semantically less connected to the investigated terms (e.g.: обезьянку - [monkey (accusativus)] appearing in the vicinity of рентгенолог [radiologist]. Table 4 summarises the results of our search for the top5 adjective collocates of the medical profession names.

TABLE 4. Top-5 adjective collocates of medical profession names in corpora: NOW and Ruscorpora

\begin{tabular}{|c|c|c|}
\hline No. & $\begin{array}{c}\text { Russian (Ruscorpora) } \\
\text { Top-5 adjectives preceding (frequency) -1 ADJ, Data retrieved: } \\
16 / 03 / 2018\end{array}$ & $\begin{array}{c}\text { English (NOW, Malaysian sub- } \\
\text { corpus) -1 ADJ; Top-5 adjectives } \\
\text { preceding (frequency); Data } \\
\text { retrieved: } 16 / 03 / 2018 \\
\end{array}$ \\
\hline 1. & $\begin{array}{l}\text { хирург: главный (chief) (105); знаменитый (renowned) (74); } \\
\text { пластический (plastic) (66); известный (famous) (37); хороший (good) } \\
\text { (30) }\end{array}$ & $\begin{array}{l}\text { surgeon: } \text { orthopaedic (45); } \\
\text { cardiothoracic (19); orthopedic (13); } \\
\text { dental (10); cosmetic(8) }\end{array}$ \\
\hline 2. & $\begin{array}{l}\text { терапевт: главный (chief) (18); мануальный (manиal) (30); } \\
\text { участковый (district-) (23); знаменитый (renowned) (5); семейный } \\
\text { (family) (3) }\end{array}$ & general practitioner: - \\
\hline 3. & $\begin{array}{l}\text { анестезиолог: опытный (experienced) (2); акушерских } \\
\text { (obstetric) (1); американский (Amеrican) (1); вменяемые (sane) } \\
\text { (1); застенчивый (huтble) (1); классные (good) (1); } \\
\text { молоденький (young) (1); наиважнейший (very important) (1); } \\
\text { операционную (operating) (1); официального (official) (1); } \\
\text { прекрасный (excellent) (1); сморщенному (wrinkled) (1); } \\
\text { сосредоточенным (concentrated) (1); стабильная (stable) } \\
\text { (1); узкоглазый (narrow-еуеd) (1) }\end{array}$ & $\begin{array}{l}\text { anesthesiologist: pediatric (3); } \\
\text { qualified (1); Malaysian (1) }\end{array}$ \\
\hline
\end{tabular}


4. рентгенолог: одновременно (simultaneоus) (1); американские (American) (1); опытный (experienced) (1); грамотный (educated) (1); главный (chief) (1); дежурных (on-duty) (1); крупнейший (outstanding) (1); обычным (ordinary) (1); отличный (excellent) (1); знаменитого (renowned) (1); известный (faтои) (1); учёные (scholarly) (1)

5. геронтолог: знаменитый (renowned) (2); британский (British) (2); американский (American) (1); выдающегося (outstanding) (1); голландские (Dutch) (1); известные (faтои) (1); немеиких (German) (1); профессиональный (professional) (1); российский (Russian) (1); ученый (scholarly) (1); японские (Japanese) (1)

6. гинеколог: известный (famous) (9); главный (chief) (6); лучший (personal) (1); cmapый (old) (1); хороший (good) (1)

7. акушер: окружной (district-) (8); главный (chief) (7); духовный (conscientious) (4); хороший (good) (3); известный (famous) (2); молодой (young) (2); прекрасный (excellent) (2); русский (Russian) (2)

8. сексолог: известный (famous) (7); современный (modern) (3); крупнейтий (outstanding) (2); опытный (experienced) (2); профессиональный (professional) (2); российские (Russian) (2)

9. ортопед: лучший (personal) (2); американских (American) (1); богатые (rich) (1); главным (chief) (1); детский (children's) (1); знакомому (acquainted) (1); известным (famous) (1); исключительно (exclusive) (1); клинических (clinical) (1); кубинских (Cuban) (1); московских (Muscovite) (1);нормальный (normal) (1); русских (Russian) (1); современные (modern) (1); уважсаемого (distinguished) (1); хорошего (good) (1); частнопрактикуюший (private) (1); шведского (Swedish) (1)

10. психотерапевт: хорошо (good) (10); известный (famous) (7); семейный (family-) (6); американский (American) (5); опытный (experienced) $(5)$

11. патологоанатом: известный (faтоиs) (4); немеикий (German) (4); видный (prominent) (3); бывиий (former) (2); крупный (major) (2)

12. физиотерапевт: бывиий (former) (1); личные (personal) (1); швейиарский (Swiss) (1)

13. стоматолог: главный (chief) (5); хороший (good) (4); одесские (from Odessa) (3); добрый (kind) (2); московским (Muscovite) (2); столичных (from the capital) (2) radiologist: interventional (8); forensic (3); chief (2); nuclear (1); diagnostic (1)

gerontologist: -

gynecologist: then-practicing (1); male (1); German (1); English (1) obstetrician: lovable (3); certified (1); American (1); 57-year-old (1)

sexologist: professional (1); female (1); clinical (1); Chinese (1)

orthopedist: general (8); regenerative (7); complex (6); Malaysian (4); degenerative (4)

psychotherapist: licensed (1); certified (1); Bosnian (1); Belgian (1) pathologist: forensic (35); Dutch (5); chemical (3); Australian (3); Thai (3) physiotherapist: part-time (3); qualified (2); royal (1); renowned (1); remote (1) dentist: Bogus (46); veteran (9); fake (8); American (7); veterinary (6)

Based on the comparison of the adjectives in Russian and (Malaysian) English corpora (Table 4) it seems evident that the Russian adjectives generally reflect (1) respect, appearing in such adjectives as знаменитый (renowned) or известный (famous); (2) expertise (опытный); and (3) social status (главный/chief). Meanwhile, the English adjectives tend to refer semantically to (1) technical aspects (part-time, professional); (2) typological features (orthopedic, pediatric, mental, interventional); and (3) regulatory aspects (licensed,forensic).

With the help of the corpus linguistic approach (Ruscorpora) it was detected that among the most typical adjectives preceding the analysed Russian medical profession names, foreign countries, nationalities, regions and towns appeared, including швейцарский (Swiss: physiotherapist); немецкий (German: radiologist, pathologist); американский (American: anesthesiologist, gerontologist, psychotherapist, physiotherapist); одесские (from Odessa); столичных (from the capital); and московский (Muscovite).

\section{CONCLUSION}

In this paper, the authors undertook the challenge of comparing Russian and Malaysian English medical profession names by relying on two linguistic research methods in parallel: the association experiment, one of the fundamental methods of the Moscow School of Psycholinguistics, and corpus linguistic research. The aim of the research was to contribute to 
the more effective work of lexicographers, translators and interpreters by shedding light on cross-cultural denotative and connotative differences between medical profession names, and to help to prevent intercultural misunderstandings, especially in the Russian-Malaysian context.

The association experiment presented in this paper proved to yield numerous results including:

1. The set-up of three categories of medical profession names as follows:

Medical profession names with

a) a strong associative field (стоматолог [dentist]; рентгенолог [radiologist]; акушер [obstetrician]; анестезиолог [anesthesiologist]; and патологоанатом [pathologist]);

b) an average-strength associative field (хирург [surgeon]; гинеколог [gynecologist]; врач спортивной медицинь [specialist in sports and exercise medicine]; пластический хирург [plastic surgeon]; and реабилитолог [rehab specialist]); and

c) a weak associative field (opmonеd (orthopedist); сексолог [seхologist]; геронтолог [gerontologist]; терапевm [general practitioner]; физиотерапевm [physiotherapist]; nсихотерапевт [physiotherapist]; and врач общественного здоровья $и$ здравоохранения [public health specialist].

2. When contrasting the English and Russian terms, a threefold classification of medical profession names was suggested as follows:

a) Nearly identical perception by both groups of language users (surgeon [хирург]; dentist [стоматолог]; radiologist [рентгенолог]; gerontologist [геронтолог]; orthopedist [opmoned]; and anesthesiologist [анестезиолог]).

b) Medical profession names with perceptions displaying relevant similarities and considerable differences at the same time (реабилитолог [rehab specialist]; врач спортивной медицины [specialist in sports and exercise medicine]; пластический хирург [plastic surgeon]; гинеколог [gynecologist]; акушер [obstetrician]; сексолог [sexologist]; nсихотерапевт [physiotherapist]; and врач общественного здоровья и здравоохранения [public health specialist]).

c) Medical profession names with remarkable differences in perception (general practitioner [mерапевт]; pathologist [патологоанатом]; physiotherapist [физиотерапевт]).

Results were contrasted to two existing associative dictionaries/thesauri, the Russian Associative Dictionary (Karaulov 2002) and the Associative Thesaurus of English (Kiss et al. 1973). It was concluded that the majority of the medical profession names (30 of 34) are not listed as a stimulus word in these sources; thus, they had a very modest contribution to our research. It was stated though, that the Russian terms reflect a more personal, individualoriented perception of medical professionals, exemplified by such adjectives as опьтниый (experienced) or хороший (good).

Corpus linguistic research in Ruscorpora (Ruscorpora 2013-2019) and in the NOW (News on the Web 2010-2019) corpus at the same time contributed considerably to further refine the result of our association experiment. Top-5 noun and adjective collocations of the 17 pairs of medical profession names displayed the following main results:

1. Medical profession names are interconnected. A remarkable number of collocations were revealed between medical profession names within the investigated 34 terms (e.g.: хирург [surgeon] and терапевm [general practitioner]; or radiologist and pathologist), and outside of our scope of observed terms (e.g.: реаниматолог (resuscitator) and 
анестезиолог [anestesiologist] or nсихотерапевт [psychotherapist] and психолог [psychologist]).

2. Morphological differences of (medical) profession names, were revealed whereas реаниматор (reanimator) and реаниматолог (resuscitator) are similar in form, but they mark different professions (both collocates of анестезиолог [anestesiologist]). It was stated that in the Russian language the suffix -олог may signal that the profession requires a degree of higher education.

3. It became evident that xupypz (surgeon) was the most frequently co-occurring term in the vicinity of other medical profession names (co-occured with mepanesm [general practitioner]; анестезиолог [anesthesiologist]; гинеколог [gynecologist]; and opтопед [orthopedist]).

4. Relying on the two applied corpora significant culture-bound information was be identified (e.g.: Фролькис [Frolkis] as a collocate of геронтолог [gerontologist] [Vladimir Frolkis, an outstanding Soviet pathologist of the $20^{\text {th }}$ century]; and Acur [Asin] for патологоанатом [pathologist] [Isaak Asin, a Soviet pathologist]).

As a summary, it was concluded that the association experiment and corpus linguistic methods complemented each other well in the comparative analysis of Malaysian English and Russian medical profession names. The research results facilitated the better understanding of the linguistic and cultural differences between the two cultures, thus contributed to lower the chance of intercultural misunderstanding and miscommunication that originates from a dissimilar perception of the investigated profession names. Additionally, the application of multiple research methods in parallel, in our view, may offer the opportunity of conducting further effective linguistic research.

\section{REFERENCES}

Almashy, A. (2016). Mixed methods in linguistics research: A critical methodological review. International Journal of Information Research and Review. Vol. 3. No. 7. 2602-2603.

Buvalin, N. (2018). A cross-cultural study of medical profession names: a comparison of Russian and international medical students' perceptions. Master's degree dissertation. Moscow: Sechenov University

Buvalin, N., Lenart, I. (2017). International communication in healthcare: A literature review. XX International Scientific-Practical Conference "Recent problems of Social Sciences." Scientific Journal Chronos. 3 October 2017. Moscow. 26-29.

Cherkasova G., Ufimtseva N. (2014). Russian Regional Associative Dictionary-Thesaurus (EVRAS). From stimulus to reaction. Russian Academy of Science. Moscow.

Crawford, P., Brown, B., Nolan., P. (1998). Communicating Care: the language of nursing. Stanley Thornes. Cheltenham (UK): Cengage Learning EMEA.

Davies, Mark. (2013). Corpus of News on the Web (NOW): 3+ billion words from 20 countries, updated every day. Https://corpus.byu.edu/now.

Gao, G., Burke, N., Somkin, C., Pasick. R. (2009). Considering Culture in Physician-Patient Communication During Colorectal Cancer Screening. Qualitative Health Research 2009 Vol. 6. 778-789.

Hughes, A., Trudgill, P., Watt, D. (2005). English Accents and Dialects: An Introduction to Social and Regional Varieties of English in the British Isles. Trans-Atlantic Publications.

Karaulov J. (2002). Russian Associative Dictionary. (Русский ассоциативный словарь). http://tesaurus.ru/dict

Karaulov, J. (2000). The index of national mentality in associative verbal chain. (Показатели национального менталитета в ассоциативно-вербальной сети). Linguistic consciousness and world view. Moscow. 191-206.

Karaulov, J., Cherkasova, G., Ufimtseva, N., Sorokin Y., Tarasov Y. (2002). Slavic Association Dictionary: Russian, Belarusian, Bulgarian, Ukrainian. (Славянский ассоциативный словарь: русский, белорусский, болгарский, украинский). Moscow: Russian Academy of Science.

Kiss, G., Armstrong, C., Milroy, R., Piper, J. (1973). An associative thesaurus of English and its computer analysis. In: Aitken, Bailey, and Hamilton-Smith, N. (Eds.). The Computer and Literary Studies. Edinburgh: University Press (restructured and documented by Michael Wilson at the Rutherford Appleton Laboratory in 1988. 
Klaudy, K. (1988). A fordítási ekvivalenciáról. (About equivalence in translation). Hungarológiai Közlemények. Novi Sad. Vol. 77. 383-396.

Lee, M. C. L, Krishnamoorthy, K., Rong, Y. R. (2019). The Role of Negotiated Interaction in L2 Vocabulary Acquisition among Primary ESL Learners. 3L: The Southeast Asian Journal of English Language Studies - Vol 25(2): 1-21. http://doi.org/10.17576/3L-2019-2502-01

Lenart, I. (2017). Associations and verbal consciousness: an analysis based on four English and one Hungarian translation of Bulgakov's novel: The Master and Margarita. Budapest: Neohelicon. Vol. 44. 487-504.

Lenart, I. (2018). Intercultural Lacunae in Hungarian-Vietnamese Communication: with Emphasis on Entrepreneurial Interactions. GlobeEdit.

Leontiev, N. (1978). Activity, consciousness, and personality (ed.: M.J. Hall Trans.). Englewood Cliffs, NJ: Prentice-Hall.

Lowenberg, P. (1991). Variation in Malaysian English: The pragmatics of languages in contact. In J. Cheshire (Ed.), English around the World: Sociolinguistic Perspectives (pp. 364-375). Cambridge: Cambridge University Press. doi:10.1017/CBO9780511611889.025

Markovina, I. (1982). The influence of linguistic and extralinguistic factors on text comprehension. (Влияние лингвистических и экстралингвистических факторов на понимание текста). Moscow

Markovina, I. (2011). The Lacuna Theory in the Research of the Problems of Intercultural Communication. [Теория лакун в исследовании проблем межкультурного общения]. LAP Lambert.

Mattingly, C. (1994). The concept of therapeutic employment. Social Science and Medicine Vol. 38. No. 6. 81122.

Meganathan, P., Yap, N. T., Paramasivam, S., Jalaluddin I. (2019). Incidental and Intentional Learning of Vocabulary among Young ESL Learners. 3L: The Southeast Asian Journal of English Language Studies - Vol 25(4): 51-67. http://doi.org/10.17576/3L-2019-2504-04

NOW Corpus (News on the Web). (2010-2019). www.corpus.byu.edu/now. (Data retrieved: March 2018.)

Pilnick, A. (1999). 'Patient counselling' by pharmacists: advice, information, or instruction? The Sociological Quarterly Vol. 40. No. 4. 613-622.

Russian National Corpus. (2003-2019). www.ruscorpora.ru. (Data retrieved: March 2018.)

Saravanamuttu, J. (2012). Malaysia-Russia Relations: Revving up a Distant Relationship. In ASEAN-Russia: Foundations and Future Prospects (pp. 184-195). ISEAS-Yusof Ishak Institute.

Shaposnikova, I., Romanenko, A. (2014). Russian Regional Associative Dictionary: Siberia and Far-East (SIBAS). Stimili to reaction. Moscow: Russian Academy of Science.

Sorokin, Y. (1985). Psycholinguistic aspects of the study of texts (Психолингвистические аспекты изучения текста). Moscow: Publishing House "Nauka.".

Tan, S. I., (2009). Lexical Borrowing in Malaysian English: Influences of Malay. Lexis [Online], 3 | 2009. URL: http://journals.openedition.org/lexis/629; DOI: https://doi.org/10.4000/lexis.629

Tarasov, E. (1996). Intercultural communication: new ontology of verbal consciousness analysis. (Межкультурное общение - новая онтология анализа языкового сознания). Moscow: Russian Academy of Science Institute of Linguistics.

Tarasov, Y. (2000). Language consciousness - research perspectives. (Языковое сознание - перспективы исследования). Языковое сознание: содержание и функционирование [Language consciousness: Content and functioning]. Moscow: Linguistic Institute of the Russian Academy of Science. 3-4.

Ufimtseva, N. (2014). The associative dictionary as a model of the linguistic picture of the world. Procedia: Social and Behavioral Sciences. Vol. 154. 36-43.

Ufimtseva, N., Cherkasova G., Karaulov, J., Tarasov, Y. (2004). Slavic Association Dictionary: Russian, Belarusian, Bulgarian, Ukrainian. (Славянский ассоциативный словарь: русский, белорусский, болгарский, украинский). Moscow: Russian Academy of Science.

Ulyanova, O., Ivushkina N., Yushkov V. (2016). Semantic peculiarities of the profession names in the sphere of health and safety protection in the Russian and English languages. Филологические науки. Вопросы теории и практики. Tambov: Publishing House "Грамота". 143-145.

Vigotsky, L. (1934). Thought and Language (Мышление и речь). Moscow-Leningrad: State Socio-Economic Publishing House.

Yakovlev, A., Mankhirova, (2015). Representation of profession names in Russian students' lexicon. Вестник ТвГУ. Серия "Филология". Krasnoyarsk: Siberial Federal University. Vol. 4. 208-213

Yamada, S. (2019). Development of Specialized Hand-held Electronic Dictionaries with Special Reference to Those for Medical Professionals and Students. 3L: The Southeast Asian Journal of English Language Studies - Vol 25(1): 1-22. http://doi.org/10.17576/3L-2019-2501-01 